\title{
Effect of Tray Drying on Quality Characteristics of Mint Leaves (Mentha spicata L.)
}

\author{
Vajrala Narendra Reddy ${ }^{*}$, P. Vijaya Deepthi, Vankalapati Venkata Saiteja, \\ Kancharla Sowmya Sri, Gudisa Mahesh Kumar and Yenni Shanmukharao
}

\author{
Department of Agricultural Engineering, Vikas College of Engineering and Technology, \\ Vijayawada Rural, Nunna (Andhra Pradesh), India
}

*Corresponding author

\section{A B S T R A C T}

\begin{tabular}{|l|}
\hline Key w or d s \\
$\begin{array}{l}\text { Rehydration ratio, } \\
\text { Sensory evaluation, } \\
\text { Blanching }\end{array}$ \\
\hline Article Info \\
\hline $\begin{array}{l}\text { Accepted: } \\
\text { 18 November } 2020 \\
\text { Available Online: } \\
\text { 10 December } 2020\end{array}$ \\
\hline
\end{tabular}

The main aim of drying agricultural products is to reduce water content to certain level at which the microbial spoilage and the deterioration by chemical reaction are greatly minimized and which allows safe storage over an extended period. Dehydrated food products can be consumed only after regaining its form by absorbing water. Mint leaves were dehydrated by using Tray dryer (Hot air dryer) in this study. To dry the fresh and blanched mint leaves using tray drying at different temperatures $\left(45^{\circ} \mathrm{C}, 50^{\circ} \mathrm{C}, 55^{\circ} \mathrm{C}\right)$ for 12 hours at a fixed air velocity of $2 \mathrm{~m} / \mathrm{s}$. Moisture content and rehydration ratio of dried product and quality characteristics by sensory evaluation can be observed and calculated. The overall study concluded that the mint leaves dried at $50^{\circ} \mathrm{C}$ in the tray dryer was accepted as compared to the other two temperatures $\left(45^{\circ} \mathrm{C}, 55^{\circ} \mathrm{C}\right)$.

\section{Introduction}

India is the one of the largest producer of vegetables in the world with an annual production of 168.6 million tonnes from 7.57 million ha with an average productivity of 22.27 tonne/ha in the year 2016-2017 (Ministry of Agriculture of central government 2018). Green leafy vegetables are being used since ancient period as source of food as they contribute protein, mineral, vitamins, fibre and other nutrients which are usually in short supply in daily diets (Solanke and Awonorin, 2002).
Mint leaves (Mentha spicata L.) are perennial herbs and grown all over the world to reap its special herbal characteristics. The most common and popular mint for cultivation is basically three types: peppermint, spear mint and apple mint. Mint is also very popular in India and mainly cultivated in southern parts of Himalayan range including Punjab, Himachal Pradesh, Haryana, Uttar Pradesh, Rajastan and Bihar.

Mint leaves contain minerals like calcium, potassium, sodium, magnesium, phosphorus and iron as well as vitamin A, C, K, folic 
acid, thiamine, riboflavin and niacin (Raghavan, 2006). Some typical secondary metabolites of Lamiaceae include various terpenoids and phenolic compounds (Aflatuni, 2005). These are known for refreshing, antiseptic, anti-asthmatic, simulative, diaphoretic, stomachic and antispasmodic features. Mint leaves can be used as a medicinal and aromatic plant and helps in colds, flu, fever, poor digestion, motion sickness, food poisoning, rheumatism, hiccups, stings, ear aches, flatulence and for throat and sinus ailments. Mint leaves are used for flavouring, tea infusions and spicing (Chawla and Thakur 2013) and also used for garnishing of foods.

Mint leaves not only used to add variety and replace extra fat, sugar and salt in meals but they also provide powerful antioxidants while adding virtually no calories. These are commonly used to produce: peppermint oil and tea, pepper mint candy, mint chocolate, chewing gum, candy care, scents and insect repellent amongst others. Mint oil is extracted either from freshly harvested leaves or from semidried or dried leaves through distillation process and this oil is used for flavouring of toothpaste, mouthwashes and chewing gum. It is also used in aromatic soaps, shampoos, perfumes, detergents and pesticides.

Mint leaves are used in both fresh and dried forms in different cuisines. Various authors (Park et al., 2002; Thompson, 2003) have revealed that use of mint leaves in a variety of dishes such as vegetable curries, chutney, fruit salads, vegetable salads, salad dressings, soups, desserts, juices, sherbets etc. Drying is the oldest method of preserving food. Drying of vegetable can be done by two methodsone is natural drying i.e sun or solar drying and another one is mechanical drying. Mechanical drying method includes tray drying, oven drying, fluidised bed drying, freeze drying and micro-wave drying.
In order to enhance the shelf life of mint leaves, to augment the availability throughout the year and to create convenience to the users, a study was carried out with following objectives that include to dry the mint leaves using tray drying at different temperatures $\left(45^{\circ} \mathrm{C}, \quad 50^{\circ} \mathrm{C}, 55^{\circ} \mathrm{C}\right)$ for 12 hours. To determine moisture content and rehydration ratio of dried product. And also to determine quality characteristics by sensory evaluation.

\section{Materials and Methods}

\section{Raw materials}

Fresh Mint leaves were selected randomly to reduce any bias from the same trader in Kaleswar Rao Market Vijayawada. The mint leaves were brought at 6:00 am in the morning to avoid any sun drying on the day they were to be pre treated.

The samples were packed in black polythene bags to keep off light and transported by road immediately to the lab that was 2 hours away.

\section{Variables under study}

Variables selected for this study were classified in three major categories as independent variables, dependent variables and fixed parameters.

\section{Fixed variables}

Air velocity of dryer: $2 \mathrm{~m} / \mathrm{s}$ (Tray dryer)

\section{Independent variables}

Drying temperature: 45,50 , and $55^{\circ} \mathrm{C}$

Equipment: Tray dryer

Pre-treatment: Blanching and Control

\section{Dependent variables}

Moisture

Moisture ratio 
Set - I Experiment

1. Total no. samples $=3$

2.Coded of the sample: $\mathrm{C}_{1}-\mathrm{C}_{3}$

3.Moisture content : $84.05 \%$ (w.b)

4.Temperature: $45^{\circ} \mathrm{C}, 50^{\circ} \mathrm{C}, \& 55^{\circ} \mathrm{C}$

5.Packaging material: Low density

polyethylene

\section{Set - II Experiment}

1. Total no. samples $=3$

2.Coded of the sample: $\mathrm{B}_{1}-\mathrm{B}_{3}$

3.Moisture content : $84.05 \%$ (w.b)

4.Temperature : $45^{\circ} \mathrm{C}, 50^{\circ} \mathrm{C}, \& 55^{\circ} \mathrm{C}$

5.Packaging material: Low density polyethylene

\section{Preparation of dried mint leaves}

Raw material: Fresh mint leaves free from Insect infestation and other impurities were selected.

Separation and washing: The leaves were separated from stalk and washed thoroughly three to four times with tap water to remove all foreign matter such as dust, dirt, chaff. After washing, leaves were spread on tissue paper to remove surface moisture.

Pre-treatment: Sorted, cleaned and washed leaves were subjected to following treatments before drying;

C - Control (without pre-treatment): The samples after initial washing were dried without any treatment (blanching)

Blanching: Cleaned mint leaves were tied in a muslin cloth and kept in boiling water $\left(80^{\circ} \mathrm{C}\right)$ for 1 minute and cooled immediately under running tap water. The extra moisture was removed using tissue papers.

Drying: The samples after treating according to the design were dried in a tray dryer for 12 hrs. The tray dryer is allowed to reach required temperature (i.e., $45^{0}, 50^{\circ} \& 55^{\circ} \mathrm{C}$ ). After reaching the temperature the samples were placed on the trays and kept for $12 \mathrm{hrs}$ for moisture evaporation. The samples after drying were packed in polyethylene covers and stored for further analysis.

\section{Description of tray dryer}

\section{Tray dryer}

A convective tray dryer was used to conduct drying experiments shown in figure 1-4 and Table 1.

Drying chamber: It comprised of an insulated box with a single door opening at front. A fan with adjustable speed for regulation of air velocity has been provided on left side of drying chamber. A heating unit for increasing the temperature of air is also provided. The air enters the drying chamber due to suction and transfers heat to the sample for drying and simultaneously, absorbs moisture from it. The moisture laden air leaves the dryer by another opening of drying chamber. The sample trays having size of 450 $\times 450 \mathrm{~mm}$ made of stainless steel were used in the dryer. The trays were stacked one over the other in a single column. Each tray could hold approximately $100 \mathrm{~g}$ of mint leaves sample uniformly in a single layer.

Heating unit: It consisted of an electric heater of $2.5 \mathrm{~kW}$. A thermostatic controller was used on the heating unit for controlling the temperature of the drying air inside the dryer. The maximum temperature of the drying air which could be attained at air velocity of $1.5 \mathrm{~m} / \mathrm{s}$ was $92^{\circ} \mathrm{C}$.

Fan: A fan provided at inner back side of drying chamber sucked the filtered atmospheric air inside and then through heating unit; forcing it to pass through the wet product placed in trays. This caused quick and 
effective drying of product. The temperature of the drying chamber was pre-set through a temperature indicator cum controller provided on control panel of dryer.

\section{Physico-chemical analysis of mint leaves}

\section{Estimation of moisture content of the samples}

The initial weight of each sample was recorded. The moisture boxes were put in the oven at $80^{\circ} \mathrm{C}$ temperature for 24 hours. The samples were then taken out of oven and cooled in the desiccators and weighed using an electronic balance having capacity of 5000 $\mathrm{g}$ and least count of $0.001 \mathrm{~g}$. The moisture content of mint leaves calculated by following formula, percentage moisture content $(\mathrm{w} . \mathrm{b})=$ $\frac{w_{1}-w_{2}}{w_{1}} * 100$

Where,

$\mathrm{W}_{1}=$ mass of original sample, $\mathrm{g}$,

$\mathrm{W}_{2}=$ mass of the sample after drying, $\mathrm{g}$.

\section{Rehydration characteristics}

Rehydration quality characteristics of dehydrated mint leaves samples were determined by rehydration test as described by Ranganna (2000).10 g of dried mint samples were taken for the experiment. 200 $\mathrm{ml}$ of distilled water in glass beakers was taken and the beakers were kept in a water bath, maintained at $80^{\circ} \mathrm{C}$. Dehydrated samples of each were placed in beakers for $10 \mathrm{~min}$. After $10 \mathrm{~min}$ the excess water was drained off through filter paper. The drained samples were weighed. Rehydration ratio (RR) and coefficient of rehydration (CR) in the dehydrated samples were computed using following equations as described by (Ranganna, 2000):

$$
\begin{aligned}
\mathrm{RR} & =\frac{\mathrm{C}}{\mathrm{D}} \\
\mathrm{CR} & =\frac{C(100-A)}{\left(D-\frac{B D}{100}\right) 100}
\end{aligned}
$$

Where,

$\mathrm{A}=$ Moisture content of samples before dehydration, (per cent wb)

$\mathrm{B}=$ Moisture content of dehydrated sample,(per cent wb)

$\mathrm{C}=$ Drained weight of rehydrated sample, $\mathrm{g}$

$\mathrm{D}=$ Weight of dehydrated samples taken for rehydration test, $\mathrm{g}$

\section{Sensory characteristics}

As quality is important in food processing, control should be exercised at every stage from pre-processing to packing, storing, etc. Quality parameters viz. sensory evaluation were determined.

\section{Organoleptic evaluation}

Quality commonly thought of as a degree of excellence, is one of the major positioning tool of the producer for marketability and for consumers satisfaction. It is the combination of characteristics of a product that have significance in determining the degree of acceptability of the product to the user. The organoleptic evaluation for assessing the colour, taste and texture was done by a panel of twenty judges using a nine point Hedonic scale (Amerine et al., 1965) as given next.

$\begin{array}{ll}\begin{array}{l}\text { Organoleptic } \\ \text { score }\end{array} & \text { Rating } \\ 9 & \text { Like extremely } \\ 8 & \text { Like very much } \\ 7 & \text { Like moderately } \\ 6 & \text { Like slightly } \\ 5 & \text { neither like nor dislike } \\ 4 & \text { Dislike slightly } \\ 3 & \text { Dislike moderately } \\ 2 & \text { Dislike very much } \\ 1 & \text { Dislike extremely }\end{array}$


The overall rating was calculated by averaging the score. The samples having score 5 and above were considered as acceptable.

\section{Results and Discussion}

The results pertaining to drying of mint leaves, moisture content, rehydration ratio, and sensory evaluation are presented in this chapter.

\section{Physico-chemical analysis of mint leaves}

\section{Initial moisture content}

The initial moisture content of fresh mint leaves and blanched leaves were determined by oven drying method as described. The average initial moisture content of fresh mint leaves and blanched leaves was found as $83.85 \%$ and $84.24 \%$ respectively.

\section{Effect of temperature and pre-treatment on moisture content}

The mint leaves with two different treatments were dried in a tray dryer and the effect of pre treatment on moisture content was studied. It was observed that the m.c of the samples without blanching reduced to $20-40 \%$ from 87.5 to $88.5 \%$.

The sample treated with blanching for 1 minute reduced to $20 \%$ from $85-88.5 \%$. It was found that the sample $\mathrm{C}_{2}$ dried at $50^{\circ} \mathrm{C}$ reduced to $20 \%$ m.c and all blanched samples showed same reduction in m.c.

\section{Effect of temperature and pre-treatment on Rehydration characteristics of dehydrated mint leaves}

During rehydration, the percentage increase in original weight of dried sample mainly depends upon the porosity of sample (Lewicki, 1998). If pre-drying treatment and drying itself would not induce any changes in the material, rehydration could be treated as a reversible process of dehydration. In practice most of the changes are irreversible and rehydration cannot be considered simply as a process reversible to dehydration (Krokida et $a l .$, 2003). Rehydration can be considered as a measure of the injury to the material caused by drying and treatment preceding dehydration (McMinn and Magee, 1997). The rehydration ratio (RR) and coefficient of rehydration (CR) of dehydrated mint leaves under different drying temperature and pretreatment was carried out as explained in Fig 5 .

The effect of different temperatures and pretreatment on rehydration ratio (RR) and coefficient of rehydration (CR) of dehydrated mint leaves results are presented in Fig 6. it can also be observed that the rehydration ratio (RR) and coefficient of rehydration (CR) gradually decreased with increase in air temperature and both values for blanched leaves are more than that of the control sample. This might be due to change in texture or structure of sample by the treatment and temperature of drying.

\section{Quality analysis of tray dried mint leaves}

The quality parameters i.e. colour and sensory evaluation of tray dried mint leaves evaluated and is discussed in this section.

\section{Sensory evaluation}

Sensory evaluation was conducted on some aspects such as colour, flavour, appearance and overall acceptability. The score ranged from 1 to 9 which represented from "Like extremely" to "Dislike extremely". Blanched and control sample of tray dried mint leaves at the temperature 45,50 and $55^{\circ} \mathrm{C}$ were served for the evaluation to six panellists at a time. The mean sensory score of tray dried mint leaves sample are shown in below table 3. 


\section{Qualitative analysis}

The colour score of dried mint leaves sample was found between 6 to 9 for control and 6 to 7 for blanched leaves. It was found maximum 7 for the blanched treatment at $50,55^{\circ} \mathrm{C}$ while in the case of control maximum 9 for the $55^{\circ} \mathrm{C}$. For flavour score ranged from $6-9$ for both control and blanched leaves. It was found maximum 8 for the blanched treatment sample at $50^{\circ} \mathrm{C}$ while in the case of control maximum 9 for the 45 and $50^{\circ} \mathrm{C}$. The appearance score of dried mint leaves sample was found between 8 to 9 for control and 6 to 7 for blanched leaves. It was found maximum 7 for the blanched sample at $50^{\circ} \mathrm{C}$ while in the case of control sample maximum 9 for the 50 and $55^{\circ} \mathrm{C}$.The overall acceptability ranged from 7.83 to 8.16 for control and 6.33 to 7.5 for blanched leaves at the various studied temperatures. It was found maximum 7.5 i.e liked very much for the blanched sample dried at $50^{\circ} \mathrm{C}$ while in the case of control maximum 8.16 i.e. liked moderately for the $50^{\circ} \mathrm{C}$ sample.

Table.1 Effect of temperature and pre treatment on m.c

\begin{tabular}{|c|l|c|c|}
\hline S.No & Sample & $\begin{array}{c}\text { Initial Moisture } \\
\text { Content }(\%)\end{array}$ & $\begin{array}{c}\text { Final moisture } \\
\text { content (\%) }\end{array}$ \\
\hline 1 & C $_{1}$ & 87.5 & 40 \\
\hline 2 & C $_{2}$ & 88 & 20 \\
\hline 3 & C $_{3}$ & 88.5 & 40 \\
\hline 4 & B $_{1}$ & 85 & 20 \\
\hline 5 & B $_{2}$ & 88.5 & 20 \\
\hline 6 & B $_{3}$ & 88.5 & 20 \\
\hline
\end{tabular}

Table.2 Rehydration ratio (RR) and coefficient of rehydration (CR) of dehydrated mint leaves in tray dryer

\begin{tabular}{|c|c|c|c|}
\hline Sample & Temperature $\left({ }^{\circ} \mathbf{C}\right)$ & RR & CR \\
\hline \multirow{2}{*}{ Control } & 45 & 3.66 & 0.972828 \\
\cline { 2 - 4 } & 50 & 3.614 & 0.720451 \\
\hline \multirow{3}{*}{ Blanched } & 55 & 3.42 & 0.909036 \\
\cline { 2 - 4 } & 45 & 2.43 & 0.484421 \\
\hline & 50 & 2.301 & 0.458704 \\
\hline & 55 & 2.718 & 0.541833 \\
\hline
\end{tabular}


Table.3 The mean sensory score of tray dried mint leaves

\begin{tabular}{|c|c|c|c|c|c|c|}
\hline Sample & Temp $\left({ }^{\circ} \mathbf{C}\right)$ & Colour & Flavour & Appearance & $\begin{array}{c}\text { Overall } \\
\text { acceptability }\end{array}$ & Remarks \\
\hline Fresh & - & 9 & 9 & 9 & 9 & $\begin{array}{c}\text { Liked very } \\
\text { extremely }\end{array}$ \\
\hline Control & 45 & 7 & 9 & 8 & 7.83 & $\begin{array}{c}\text { Liked } \\
\text { moderately }\end{array}$ \\
\cline { 2 - 7 } & 50 & 6 & 9 & 9 & 8.16 & $\begin{array}{c}\text { Liked } \\
\text { slightly }\end{array}$ \\
\cline { 2 - 7 } & 55 & 9 & 6 & 9 & 7.83 & $\begin{array}{c}\text { Liked } \\
\text { slightly } \\
\text { Llanched }\end{array}$ \\
\hline \multirow{2}{*}{ Blancd } & 45 & 7 & 6 & 6 & 6.33 & $\begin{array}{c}\text { Liked } \\
\text { slightly }\end{array}$ \\
\cline { 2 - 7 } & 50 & 7 & 8 & 7 & 7.5 & $\begin{array}{c}\text { Liked } \\
\text { moderately }\end{array}$ \\
\cline { 2 - 7 } & 55 & 6 & 7 & 6 & 6.66 & $\begin{array}{c}\text { Liked } \\
\text { slightly }\end{array}$ \\
\hline
\end{tabular}

Fig.1 Tray dryer

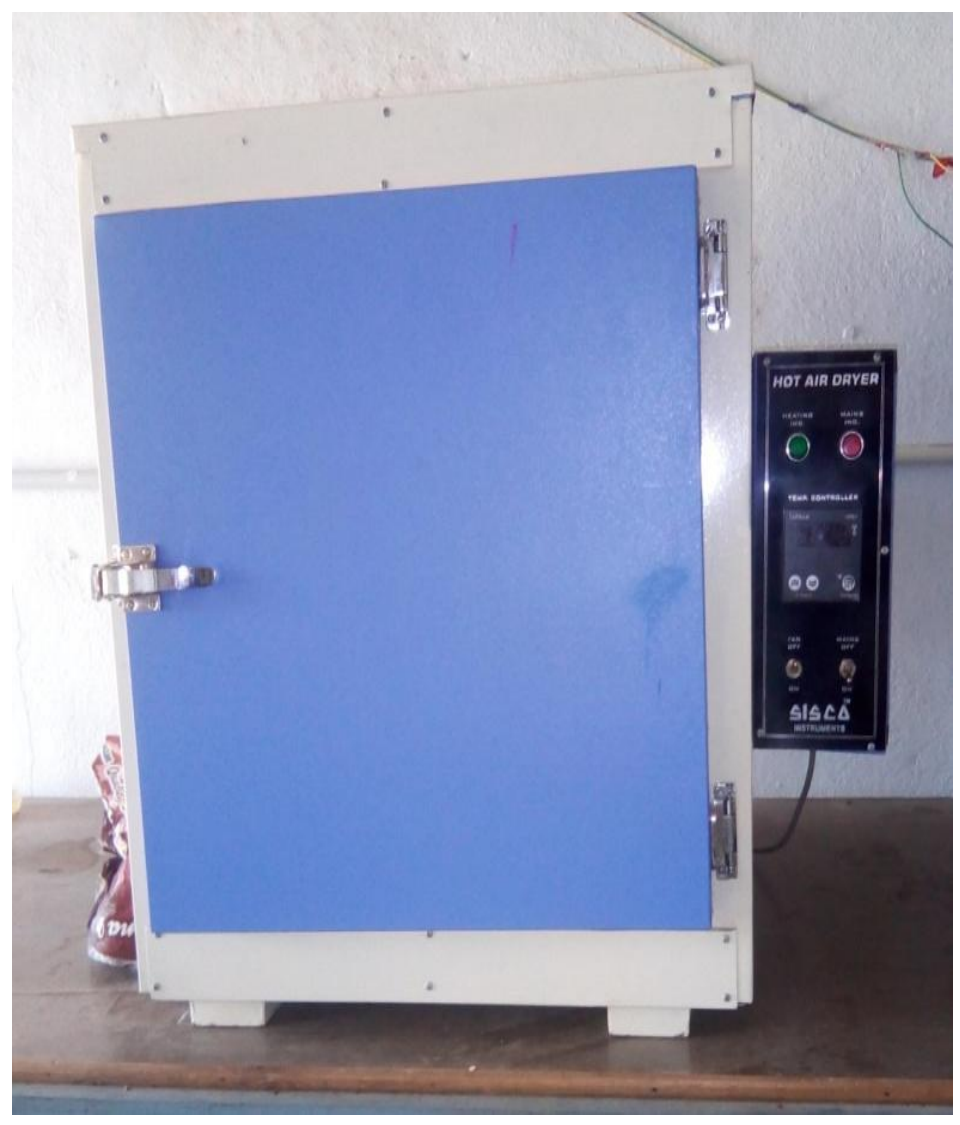


Fig.2 Control (A) and blanched samples (B)of mint leaves dried at $45^{\circ} \mathrm{C}$ in tray dryer

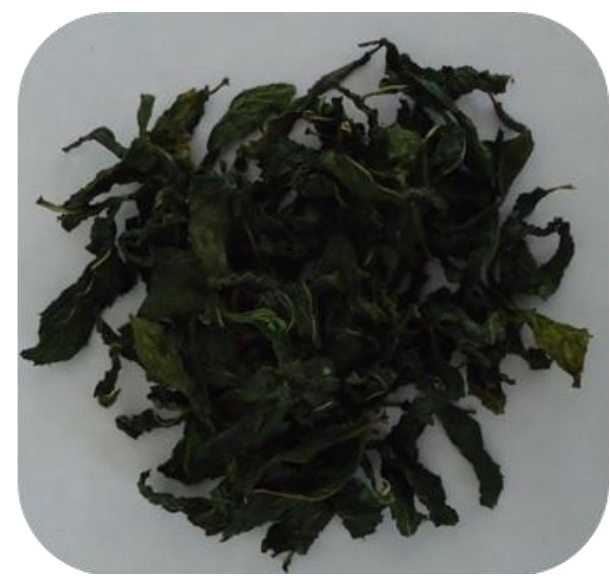

(A)

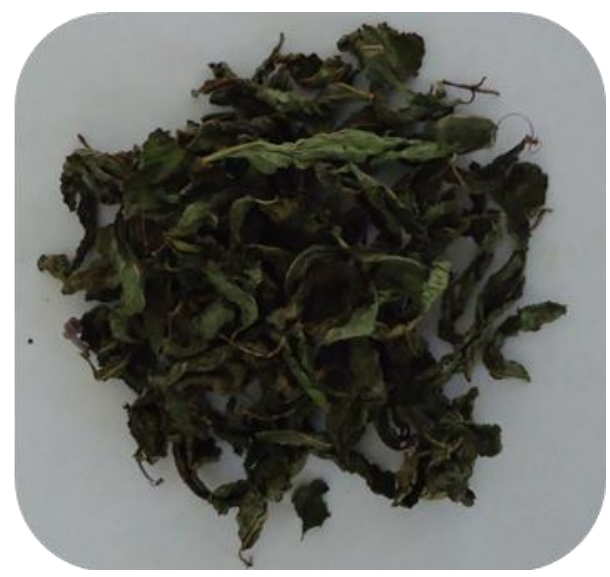

(B)

Fig.3 Control(C) and blanched samples (D)of mint leaves dried at $50^{\circ} \mathrm{C}$ in tray dryer

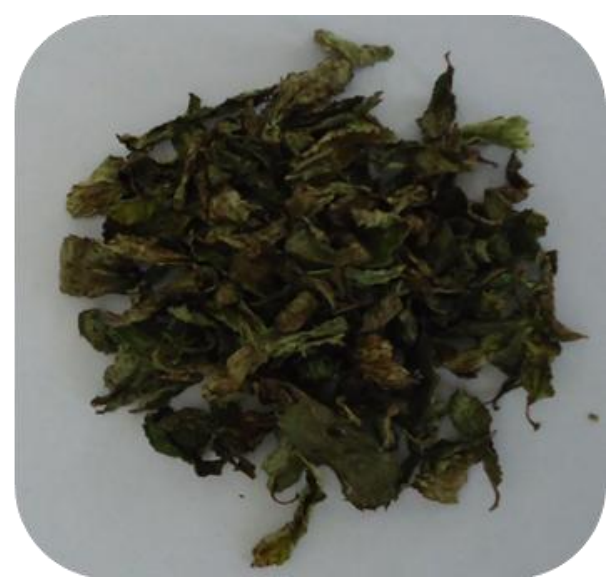

(C)

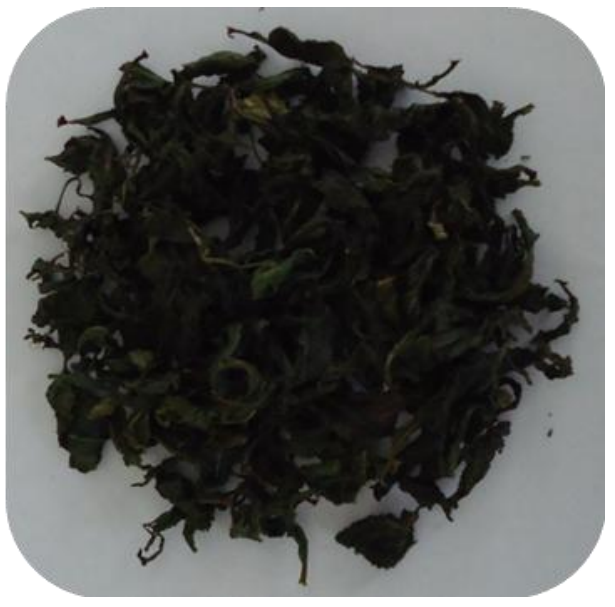

(D)

Fig.4 Control (E) and blanched (F) samples of mint leaves dried at $55^{\circ} \mathrm{C}$ in tray dryer

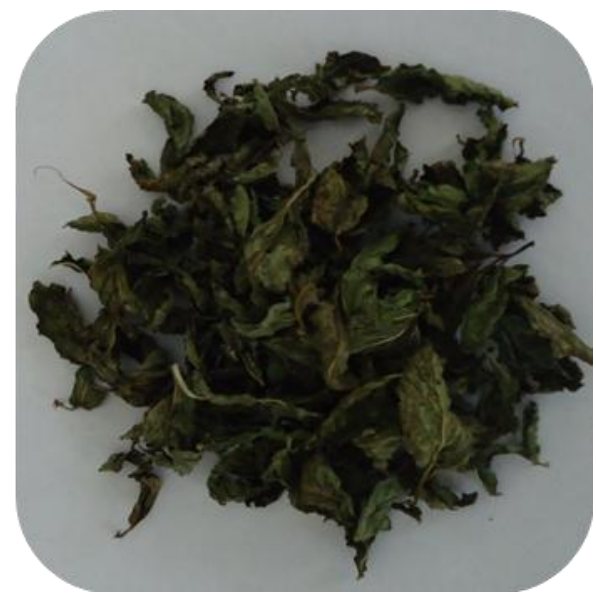

(E)

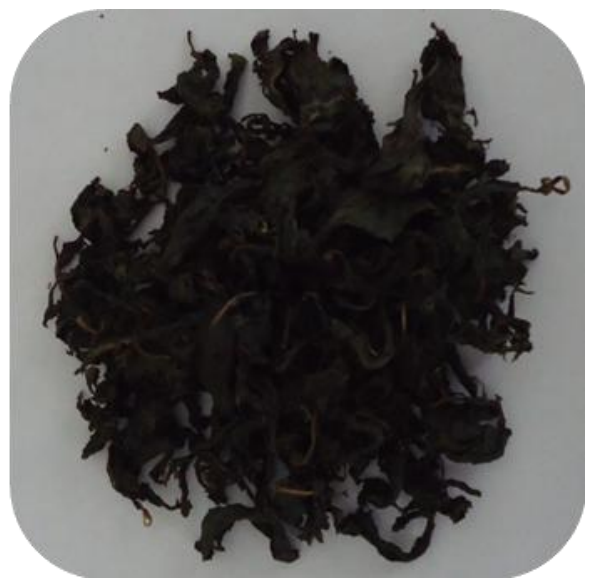

(F) 
Fig.5 Initial and final moisture contents

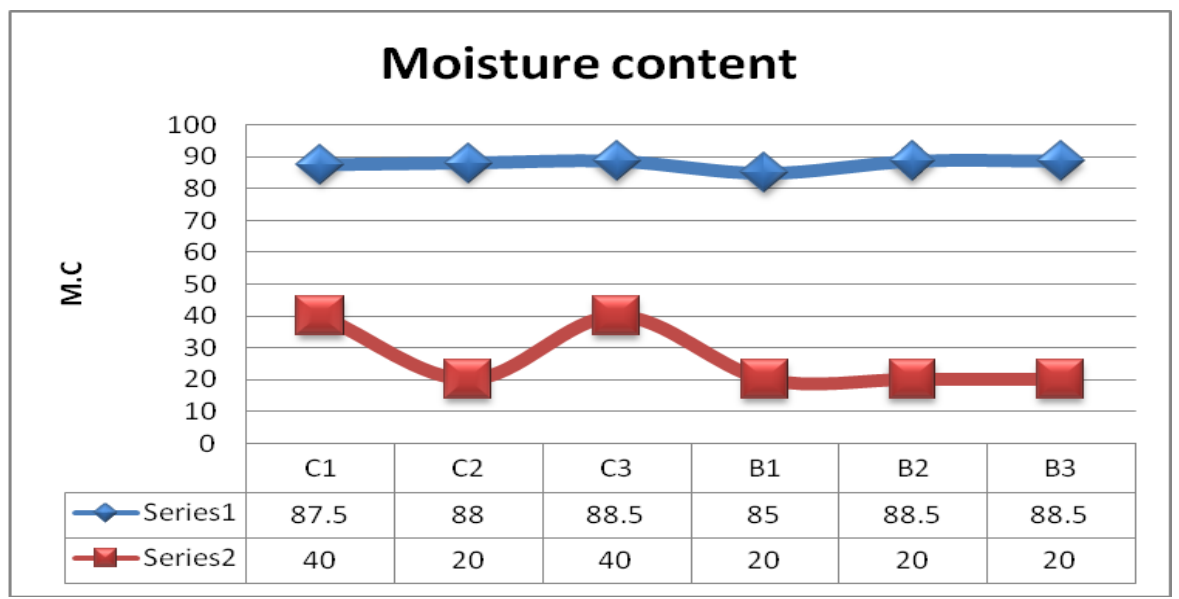

Fig.6 Rehydration ratio

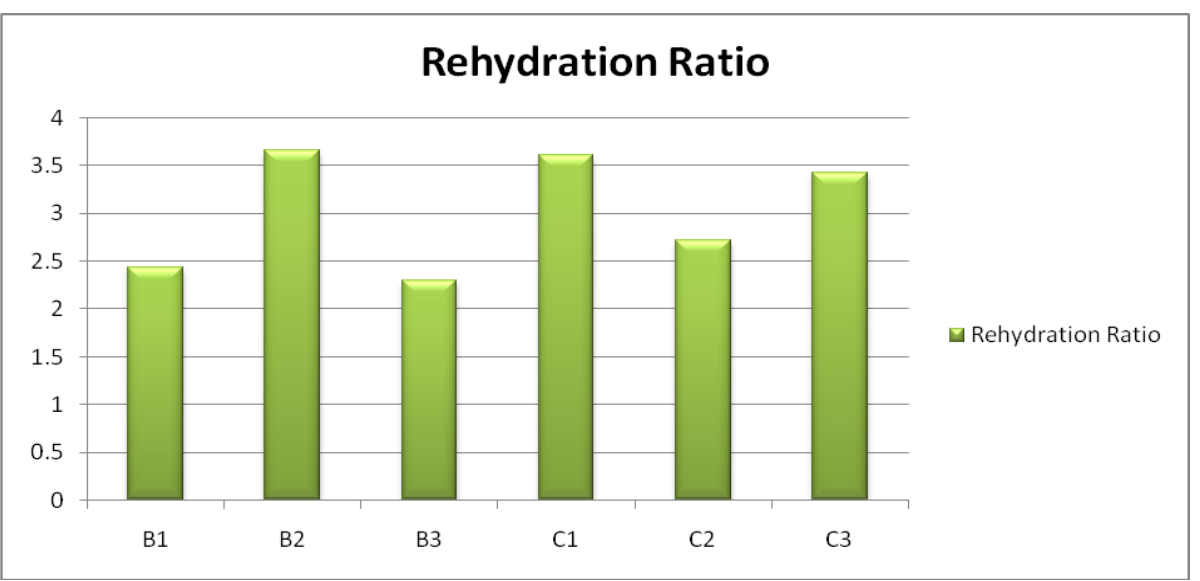

Fig.7 Rehydration coefficient

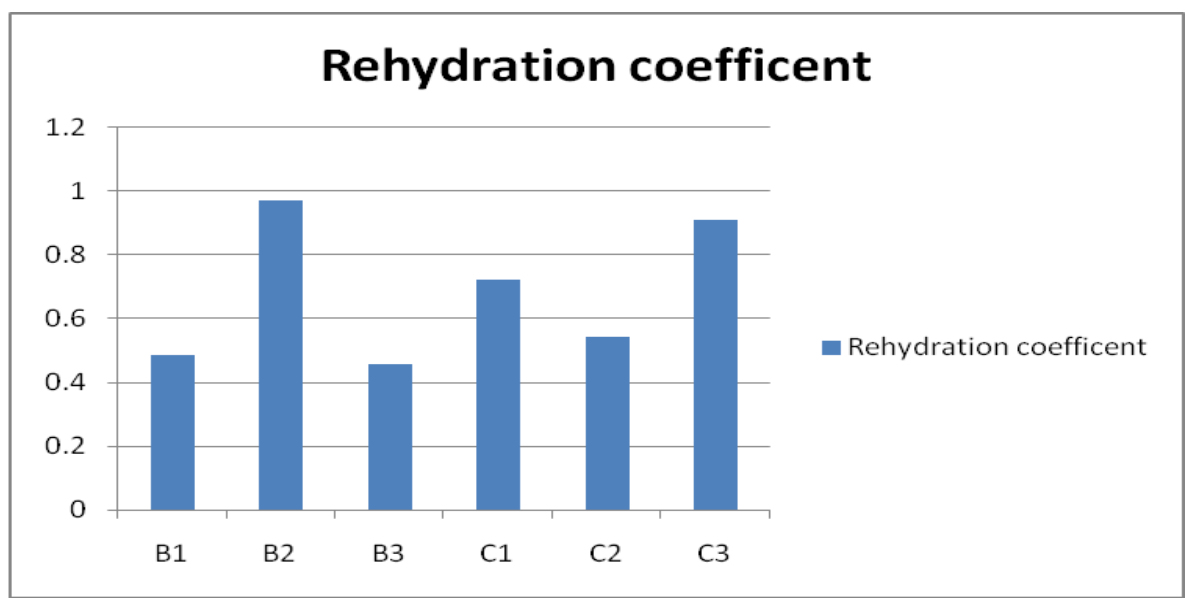


Fig.8 Qualitative Evaluation

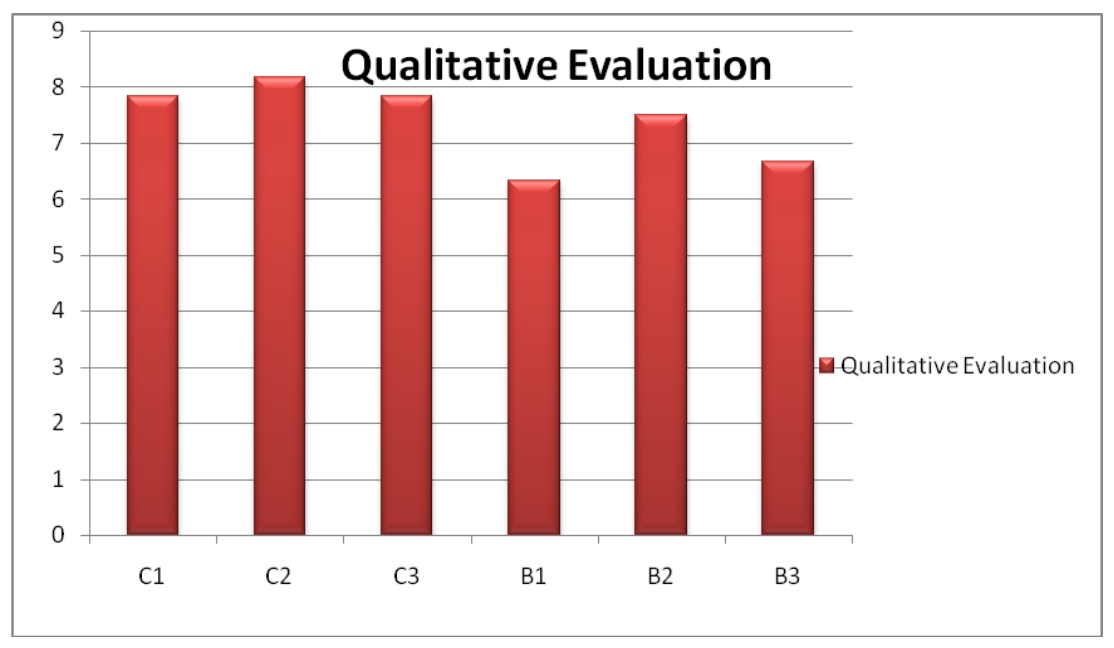

In conclusion the dried mint leaves were successfully produced in tray dryer at different temperatures $45,50 \& 55^{\circ} \mathrm{C}$ using two pretreatments. The moisture content of the samples produced from control reduced from $84.04 \%$ to $20 \%$ and from blanching reduced from $86.30 \%$ to $20 \%$. Rehydration ratio and rehydration coefficient was found to all the samples at selected temperatures. Sensory evaluation has been done to find the acceptable sample.

\section{References}

1.Aflatuni, A. 2005. The yield and essential oil content of mint (Mentha ssp.) in Northern Ostrobothnia. Oulun Yliopisto.

2.Aghbashlo, M., Kianmehr, M. H., Khani, S. and Ghasemi, M. 2009. Mathematical modelling of thin-layer drying of carrot. International Agrophysics, 23(4): 313317.

3.Ahmed, J., Shivhare, U. S.and Singh, G. 2001. Drying characteristics and product quality of coriander leaves. Food and bio products processing, 79(2):103-106.

4.Akbari, S.H., Patel, N. C. and Joshi, D. C. 2001. Studies on dehydration of onion.
Paper presented at ASAE Annual Meet held at Sacromento, CA, USA during July 29-Aug 1, Paper No.016023.

5.Akonor, P. T. and Amankwah E. A. 2012. Thin Layer Drying Kinetics of SolarDried Amaranthus hybridus and Xanthosoma sagittifolium Leaves. Journal of Food Processing and Technology, 10(3): 92-96.

6.Akpinar, E. K. 2006. Mathematical modelling of thin layer drying process under open sun of some aromatic plants. Journal of Food Engineering, 77(4): 864-870.

7.Alankar, S. 2009. A review on peppermint oil. Asian Journal of Pharmaceutical and Clinical Research, 2(2):27-33.

8.Amerine, M.S., Pangborn, R.M. and Rossler, E.A. 1965. Principles of sensory evaluation of food. Academics Press, New York.

9.Ankita and Prasad, K. 2013. Studies on spinach powder as affected by dehydration temperature and process of blanching. International Journal of Agriculture and Food Science Technology, 4 (4):309-316.

10.Arora, S., Shivhare, U. S., Ahmed, J. and Raghavan, G. S. V. 2003. Drying kinetics of Agaricus bisporus and 
Pleurotus florida mushrooms. Agricultural Engineers, 46(3):721-724.

Transactions-American Society of

\section{How to cite this article:}

Vajrala Narendra Reddy, P. Vijaya Deepthi, Vankalapati Venkata Saiteja, Kancharla Sowmya Sri, Gudisa Mahesh Kumar and Yenni Shanmukharao. 2020. Effect of Tray Drying on Quality Characteristics of Mint Leaves (Mentha spicata L.). Int.J.Curr.Microbiol.App.Sci. 9(12): 28732883. doi: https://doi.org/10.20546/ijcmas.2020.912.342 